\title{
Infectious SARS-CoV-2 is rarely present in the nasopharynx samples collected from Swedish hospitalized critically ill COVID-19 patients
}

\author{
Jiaxin Ling ${ }^{1} \cdot$ Rachel A. Hickman ${ }^{1,4} \cdot$ Robert Frithiof $^{2} \cdot$ Michael Hultström $^{2,3} \cdot$ Josef D. Järhult $^{4} \cdot$ Åke Lundkvist $^{1}$. \\ Miklos Lipcsey ${ }^{2,5}$
}

Received: 18 February 2022 / Accepted: 21 February 2022 / Published online: 7 March 2022

(c) The Author(s) 2022

The coronavirus disease 2019 (COVID-19) pandemic is still rapidly spreading. It is still unclear to what extent patients with COVID-19 treated at the intensive care unit (ICU) shed infectious severe acute respiratory syndrome coronavirus 2 (SARS-CoV-2). Yet, this has important implications for infection control and disease management as well as for the understanding of the pathobiology of COVID-19 at the ICU [1]. Consequently, in a prospective study, we isolated SARSCoV-2 from nasopharynx (NPH) samples from COVID-19 patients admitted to ICU with severe respiratory failure at the Uppsala University Hospital, between December 2020 and June 2021 (including the second half of the second wave, and the third wave). The study was approved by the National Ethical Review Agency (EPM; No. 2020-05,730). Informed consent was obtained from each patient, or next of kin if the patient was unable to give consent. The Declaration of Helsinki and its subsequent revisions were followed.

In brief, NPH samples were collected consequently from the patients twice a week during the first 2 weeks at the ICU, and then once a week until discharge from the ICU or death.

Jiaxin Ling

Jiaxin.ling@imbim.uu.se

$\bowtie$ Miklos Lipcsey

miklos.lipcsey@surgsci.uu.se

1 Department of Medical Biochemistry and Microbiology, Zoonosis Science Center, Uppsala University, Uppsala, Sweden

2 Department of Surgical Sciences, Anesthesia and Intensive Care Medicine, Uppsala University, Uppsala, Sweden

3 Integrative Physiology, Department of Medical Cell Biology, Uppsala University, Uppsala, Sweden

4 Department of Medical Sciences, Zoonosis Science Center, Uppsala University, Uppsala, Sweden

5 Hedenstierna Laboratory, Department of Surgical Sciences, Anesthesiology and Intensive Care, CIRRUS, Uppsala University, Uppsala, Sweden
We collected $199 \mathrm{NPH}$ samples from 124 patients. The NPH samples were immediately stored in $2 \mathrm{~mL}$ of viral transfer media (HBSS supplemented with $2 \%$ FBS, $100 \mu \mathrm{g} / \mathrm{mL}$ gentamicin, and $0.5 \mu \mathrm{g} / \mathrm{mL}$ amphotericin B) and delivered on ice to the Zoonosis Science Center the same day [2]. A total of $280 \mu \mathrm{L}$ of each sample was used for a viral qRT-PCR test based on the $\mathrm{N}$ and E genes of SARS-CoV-2, and $100 \mu \mathrm{L}$ was used for virus isolation in our biosafety level 3 laboratory, as described previously [3]. Infected cells were checked for development of cytopathic effect (CPE) as compared to uninfected control cells for at least two passages. Once CPE was observed, the supernatant was collected and put in TRIzol ${ }^{\circledR}$ (Thermo Fisher, USA) for inactivation and further analysis by qRT-PCR as described earlier [4, 5].

We isolated four SARS-CoV-2 strains from four individual patients (3.2\% of the cohort) as confirmed by both CPE development in Vero E6 cells and by a qPCR cycle threshold $(\mathrm{Ct})$ value below 20. For data analysis, we used the lower of the two Ct values obtained by the qPCRs targeting the $\mathrm{N}$ and $\mathrm{E}$ genes, respectively, for each sample. These four culturable samples had a lower $\mathrm{Ct}$ median values of 22.5 (interquartile range (IQR), 21-25; Fig. 1) as compared to 32.5 (IQR, 27-36) $(p<0.01)$ for the non-culturable NPH samples, which was in line with other studies [6-8]. According to the recommendation by the Centers for Disease Control and Prevention, transmission-based precautions should be taken for non-immunocompromised patients for at least 10 days from the first positive test [9]. In a previous report, $17.8 \%$ (23/129) of high-dependency or ICU patients had culturable SARS-CoV-2 virus at some time-point, and it was approximated that less than $5 \%$ have culturable virus 15 days after onset of symptoms [10]. Our findings of culturable virus in 4/124 ICU patients at least 10 days after the onset of the symptoms were similar or lower than previously reported, possibly explained by differences in case mix and the sampling time during the disease course. 
No differences in duration of COVID-19, demography, previous medical history, or organ function were found between the group of patients with culturable infection and the group of patients with non-culturable infections (Table 1). However, blood hemoglobin levels and red blood cell counts on ICU admission were lower $(p<0.01)$ among patients with culturable virus potentially resulting from SARS-CoV-2-induced hemoglobin denaturation, and aggravating hypoxemia [11]. We acknowledge that the study was limited by the low statistical power given the low number of cases with culturable SARS-CoV-2.

In conclusion, we found 4 of 124 patients were shedding infectious virus up to 26 days after symptom onset, suggesting that SARS-CoV-2 is rarely culturable from the nasopharynx in hospitalized critically ill COVID-19 patients. However, we could not identify specific clinical characteristics
Table 1 Patient characteristics in patients with and without positive virus cultures of SARSCoV-2. Data presented as median (IQR) unless otherwise stated

\begin{tabular}{|c|c|c|}
\hline & $\begin{array}{l}\text { Virus could not be cultured } \\
(n=120)\end{array}$ & $\begin{array}{l}\text { Virus could be } \\
\text { cultured }(n=4)\end{array}$ \\
\hline Female $n(\%)$ & $37(31)$ & $1(25)$ \\
\hline Age (yrs) & $64(54-71)$ & $74(58-78)$ \\
\hline Body weight & $92(82-105)$ & $81(72-102)$ \\
\hline BMI $\left(\mathrm{kg} / \mathrm{cm}^{2}\right)$ & $30(27-35)$ & $26(24-34)$ \\
\hline \multicolumn{3}{|l|}{ Previous medical history } \\
\hline Pulmonary disease & $29(24)$ & - \\
\hline Hypertension & $67(56)$ & $2(50)$ \\
\hline Ischemic heart disease & $12(10)$ & - \\
\hline Diabetes mellitus & $31(25)$ & $2(50)$ \\
\hline \multicolumn{3}{|l|}{ Organ support in the ICU } \\
\hline Renal replacement therapy & $2(2)$ & - \\
\hline Invasive ventilation & $66(55)$ & $1(25)$ \\
\hline $\mathrm{PaO}_{2} / \mathrm{FiO}_{2}$ ratio on admission & $17.3(15.9-20.7)$ & $18(12.4-20.2)$ \\
\hline Lowest $\mathrm{PaO}_{2} / \mathrm{FiO}_{2}$ ratio during ICU stay & $11.0(8.7-12.8)$ & $10.6(8.7-13.8)$ \\
\hline \multicolumn{3}{|l|}{ Vital signs on admission to the ICU } \\
\hline Breathing rate $(/ \mathrm{min})$ & $28(22-33)$ & $23(10-29)$ \\
\hline Heart rate $(/ \mathrm{min})$ & $85(75-96)$ & $67(65-105)$ \\
\hline Mean arterial pressure $(\mathrm{mmHg})$ & $90(78-103)$ & $97(71-102)$ \\
\hline Body temperature $\left({ }^{\circ} \mathrm{C}\right)$ & $37.4(36.9-37.9)$ & $37.8(37.6-37.9)$ \\
\hline SAPS3 & $53(47-58)$ & $37(37-37)$ \\
\hline Days after symptoms onset & $10(9-12)$ & $10(7-26)$ \\
\hline \multicolumn{3}{|l|}{ Laboratory values on ICU admission } \\
\hline Blood Hemoglobin (g/L) & $132(121-144)$ & $110(96-126)^{*}$ \\
\hline Plasma CRP (mg/L) & $129(65-200)$ & $132(50-259)$ \\
\hline Plasma Procalcitonin $(\mu \mathrm{g} / \mathrm{L})$ & $0.3(0.1-0.6)$ & $0.1(0.1-7.9)$ \\
\hline Blood WBC $\left(\times 10^{9}\right)$ & $7.6(5.6-10.6)$ & $8.7(5.7-11.8)$ \\
\hline Blood RBC $\left(\times 10^{12}\right)$ & $4.5(4.1-4.8)$ & $3.9(3.3-4.2)^{*}$ \\
\hline Blood Platelets $\left(\times 10^{9}\right)$ & $245(182-292)$ & $197(136-314)$ \\
\hline Plasma Creatinine $(\mu \mathrm{mol} / \mathrm{L})$ & $73(61-93)$ & $72(70-446)$ \\
\hline \multicolumn{3}{|l|}{ Maximal laboratory values during ICU stay } \\
\hline Blood Hemoglobin (g/L) & $145(132-154)$ & $125(111-139)$ \\
\hline Plasma CRP (mg/L) & $195(130-275)$ & $224(156-297)$ \\
\hline Plasma Procalcitonin $(\mu \mathrm{g} / \mathrm{L})$ & $0.5(0.2-1)$ & $7.3(0.4-15)$ \\
\hline Blood WBC $\left(\times 10^{9}\right)$ & $14.2(11-17.7)$ & $16(10.2-20.5)$ \\
\hline Blood RBC $\left(\times 10^{12}\right)$ & $4.7(4.3-5)$ & $4.2(3.5-4.3)^{*}$ \\
\hline Blood Platelets $\left(\times 10^{9}\right)$ & $444(355-513)$ & $353(230-588)$ \\
\hline Plasma Creatinine $(\mu \mathrm{mol} / \mathrm{L})$ & $80(68-105)$ & $91(73-588)$ \\
\hline
\end{tabular}

$B M I$ body mass index, CRP C-reactive protein, COVID-19 coronavirus disease 2019, ICU intensive care unit, SAPS3 Simplified Acute Physiology Score 3, WBC white blood cell count, $R B C$ red blood cell count $* p<0.05$ 


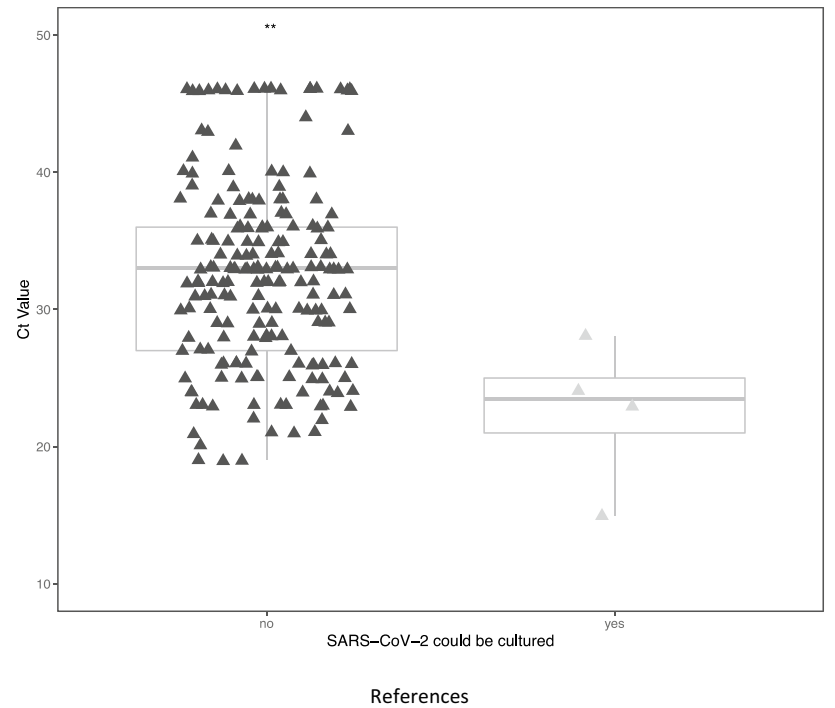

Fig. 1 qRT-PCR data in patients with and without positive virus cultures of SARS-CoV-2. The lower $\mathrm{Ct}$ value from $\mathrm{N}$ gene- and $\mathrm{E}$ genebased qPCR examination was plotted for each sample. The Student $t$ test was used for comparing the groups

except the hemoglobin level and the red blood cell counts identifying patients with culturable SARS-CoV-2.

Acknowledgements The authors thank research nurses Joanna Wessbergh and Elin Söderman for their expertise in compiling patient data, and biobank assistants Erik Danielsson, Philip Karlsson, Labolina Spång, and Amanda Svensson for their help with patient inclusion and sample collection.

Author contribution M.L. analyzed and interpreted the patient data regarding the patient characteristics in patients with and without positive virus cultures of SARS-CoV-2. J.L. performed the virus isolation attempts and virological assessment. J.L. and M.L. wrote the original manuscript and all authors contributed in writing the manuscript. All authors read and approved the final manuscript.

Funding This work was supported by Börjesson E o R stipends foundation (J.L.) and grants from the SciLifeLab/Knut and Alice Wallenberg national COVID-19 research program (M.H.: KAW 2020.0182, KAW 2020.0241, and J.J., J.L., Å.L.: KAW 2020.0241, V-2020-0699, project "MOLRES"), SciLifeLab:s program for pandemic preparedness (Å.L., J.J.: project "ZSC-National core facility for Pandemic Preparedness" (VC-2021-0033)), the Swedish Heart-Lung Foundation (M.H.: 20210089, 20190639, 20190637), and the Swedish Research Council (R.F.: 2014-02569, 2014-07606).

Data availability The datasets used and/or analyzed during the current study are available from the corresponding author on reasonable request.

\section{Declarations}

Ethics approval and consent to participate The study was approved by the National Ethical Review Agency (EPM; No. 2020-05730). Informed consent was obtained from each patient, or next of kin if the patient was unable give consent. The Declaration of Helsinki and its subsequent revisions were followed.

Consent for publication Not applicable.

Competing interests The authors declare no competing interests.

Open Access This article is licensed under a Creative Commons Attribution 4.0 International License, which permits use, sharing, adaptation, distribution and reproduction in any medium or format, as long as you give appropriate credit to the original author(s) and the source, provide a link to the Creative Commons licence, and indicate if changes were made. The images or other third party material in this article are included in the article's Creative Commons licence, unless indicated otherwise in a credit line to the material. If material is not included in the article's Creative Commons licence and your intended use is not permitted by statutory regulation or exceeds the permitted use, you will need to obtain permission directly from the copyright holder. To view a copy of this licence, visit http://creativecommons.org/licenses/by/4.0/.

\section{References}

1. Phua J, Weng L, Ling L et al (2020) Intensive care management of coronavirus disease 2019 (COVID-19): challenges and recommendations. Lancet Respir Med 8(5):506-517. https://doi.org/10. 1016/S2213-2600(20)30161-2

2. Mears MJ, Wallace MJ, Yount JS et al (2021) Viral transport media for COVID-19 testing. MethodsX 8

3. Akaberi D, Krambrich J, Ling J et al (2020) Mitigation of the replication of SARS-CoV-2 by nitric oxide in vitro. Redox Biol 101734. https://doi.org/10.1016/j.redox.2020.101734

4. Wang D, Hu B, Hu C et al (2020) Clinical characteristics of 138 hospitalized patients with 2019 novel coronavirus-infected pneumonia in Wuhan, China. JAMA. https://doi.org/10.1001/jama.2020.1585

5. Corman VM, Landt O, Kaiser M et al (2020) Detection of 2019 novel coronavirus (2019-nCoV) by real-time RT-PCR. Euro Surveill 25(3). https://doi.org/10.2807/1560-7917.ES.2020.25.3. 2000045

6. Wolfel R, Corman VM, Guggemos W et al (2020) Virological assessment of hospitalized patients with COVID-2019. Nature 581(7809):465469. https://doi.org/10.1038/s41586-020-2196-x

7. Bullard J, Dust K, Funk D et al (2020) Predicting infectious severe acute respiratory syndrome coronavirus 2 from diagnostic samples. Clin Infect Dis 71(10):2663-2666. https://doi.org/10.1093/ $\mathrm{cid} / \mathrm{ciaa} 638$

8. La Scola B, Le Bideau M, Andreani J et al (2020) Viral RNA load as determined by cell culture as a management tool for discharge of SARS-CoV-2 patients from infectious disease wards. Eur J Clin Microbiol Infect Dis 39(6):1059-1061. https://doi.org/10.1007/ s10096-020-03913-9

9. CDC (2021) Interim infection prevention and control recommendations for healthcare personnel during the coronavirus disease 2019 (COVID-19) pandemic.

10. van Kampen JJA, van de Vijver D, Fraaij PLA et al (2021) Duration and key determinants of infectious virus shedding in hospitalized patients with coronavirus disease-2019 (COVID-19). Nat Commun 12(1):267. https://doi.org/10.1038/s41467-020-20568-4

11. Cavezzi A, Troiani E, Corrao S (2020) COVID-19: hemoglobin, iron, and hypoxia beyond inflammation. A narrative review Clin Pract 10(2):1271. https://doi.org/10.4081/cp.2020.1271

Publisher's Note Springer Nature remains neutral with regard to jurisdictional claims in published maps and institutional affiliations. 